\title{
MOTIVASI BELAJAR DAN FAKTOR-FAKTOR YANG BERPENGARUH: SEBUAH KAJIAN PADA INTERAKSI PEMBELAJARAN MAHASISWA
}

\author{
Irmalia Susi Anggraini *
}

\begin{abstract}
It has been theoretically approved that motivation has become the most dominant factor which influence students' achievement. Motivation is the generator of the learning process; and it will be essential to know where the motivation comes from. This study concerns on factors which influence the learning motivation for the student of Economy Study Program, State University of Malang. Motivation is cited as the independent variable which is measured by: (1) possession of literatures; (2) frequency of questioning to lecturer; (3) punctuality in completing individual work; and (4) percentage of attendance. The dependent variables of motivation are intrinsic and extrinsic. The result of the analysis shows that: (1) the significant internal factors are intention and orientation in choosing the study program; and (2) the significant external factors are quality of lecturer, lectures content, instructional method, classroom circumference and library support.
\end{abstract}

Key words: Learnign motivation, Learning Interaction

\begin{abstract}
Abstrak
Berdasarkan teori motivasi menjadi faktor paling dominan yang mempengaruhi proses dan hasil pembelajaran. Motivasi meningkatkan minat belajar, perbedaan Motivasi menjadi daya penggerak dalam pembelajaran, tapi yang harus diperhatikan adalah dari mana motivasi itu datang. Penelitian ini mengkaji faktor-faktor yang dapat mempengaruhi bagaimana meningkatkan motivasi bagi mahasiswa di Program Studi Ekonomi, Universitas Negeri Malang. Motivasi merupakan variabel dependen yang diukur dengan: (1) memiliki literatur; (2) frekuensi bertanya pada dosen; (3) ketepatan mengerjakan tugas individu; dan (4) tingkat kehadiran mahasiswa dalam perkuliahan. Variabel independen dari motivasi adalah intrinsik dan ekstrinsik. Berdasarkan hasil analisis data menyimpulkan faktor-faktor yang mempengaruhi motivasi adalah (1) faktor internal, termasuk minat terhadap ilmu yang dipelajari dan orientasinya dalam mengikuti pendidikan tinggi; dan (2) faktor eksternal, termasuk kualitas dosen yang mengajar, isi pembelajaran,
\end{abstract}

* Irmalia Susi Anggraini adalah Dosen Prodi PGSD IKIP PGRI Madiun 
metode pembelajaran yang digunakan, kondisi dan suasana ruang kuliah serta fasilitas perpustakaan yang dapat dimanfaatkan mahasiswa.

Kata kunci: Motivasi Belajar, Interaksi Pembelajaran

\section{A. PENDAHULUAN}

Rendahnya motivasi belajar mahasiswa sering dianggap sebagai penyebab rendahnya kualitas lulusan sebuah perguruan tinggi. Pada kebanyakan perguruan tinggi swasta, faktor ini bahkan menimbulkan persoalan dilematis, karena dengan rendahnya motivasi belajar, sebenarnya tidak mungkin mahasiswa dapat menguasai bahan pembelajaran dengan baik, namun harus diluluskan demi kelangsungan perguruan tinggi tersebut. Praktik seperti ini menjadi aman dan langgeng, karena secara tidak langsung didukung oleh kebanyakan mahasiswa yang tujuan utamanya hanya sekedar untuk memperoleh gelar kesarjanaan saja, dan bukan untuk menguasai ilmu pengetahuan. Sementara, banyak perguruan tinggi yang salah kaprah dalam menerapkan konsep kepuasan pelanggan dalam dunia pendidikan, sehingga memudahkan mahasiswa lulus dianggap sebagai memberikan kepuasan terhadap konsumennya (mahasiswa).

Masyarakat Indonesia semakin rasional, sehingga lulusan perguruan tinggi

tidak lagi dipandang dari gelar kesarjanaannya saja, melainkan dari konseptual/pemikirannya. Gelar kesarjanaan tidak lagi menjadi tujuan utama seseorang dalam mengikuti pendidikan tinggi, melainkan penguasaan ilmu pengetahuan. Akan terjadi seleksi alamiah dimana hanya orang-orang yang benarbenar ingin menguasai bidang ilmu tertentu saja, yang akan melanjutkan ke jenjang pendidikan yang lebih tinggi. Sedangkan orang-orang yang hanya berburu gelar kesarjanaan saja akan menjadi out of date. Pada kondisi itu, maka kinerja perguruan tinggi tidak lagi diukur dalam menghasilkan sebanyak-banyaknya sarjana, melainkan dari kemampuan dalam menghasilkan sebanyak-banyaknya sarjana yang berkualitas, yang diukur dari penguasaan terhadap ilmu pengetahuan.

Dewasa ini, seiring dengan pertumbuhan perguruan tinggi yang makin pesat, maka tingkat persaingan di antara perguruan tinggi dalam memperebutkan calon mahasiswa, juga menjadi semakin ketat. Hanya tersedia satu jalan bagi perguruan tinggi yang ingin bertahan dalam persaingan tersebut, yaitu melalui kualitas lulusan yang dihasilkannya. Banyak contoh dimana lulusan perguruan tinggi tidak diterima bekerja pada suatu perusahaan, karena melalui proses penyeleksian terbukti bahwa gelar kesarjanaan yang dimilikinya tidak sebanding dengan konseptual/pemikirannya. Perguruan tinggi yang menghasilkan lulusan seperti ini sebenarnya hanya tinggal menunggu waktu saja untuk ditinggalkan calon mahasiswanya.

Dapat dikatakan bahwa motivasi belajar mahasiswa merupakan faktor yang paling menentukan dalam menciptakan sarjana yang berkualitas. Sehingga sejalan dengan tekad Universitas Negeri Malang untuk menghasilkan sarjana yang berkualitas, tekad itu kiranya dibarengi dengan upaya untuk meningkatkan motivasi belajar mahasiswanya. Penelitian ini bermaksud untuk mencari tahu, faktor-faktor yang mempengaruhi motivasi belajar mahasiswa, sehingga darinya 
dapat diperoleh masukan untuk merumuskan kebijakan yang tepat untuk meningkatkannya.

\section{B. KAJIAN PUSTAKA}

1. Teori Motivasi

Pemuasan kebutuhan merupakan tujuan dari motif yang menggerakkan seseorang. Berdasarkan Gambar 1 motivasi dapat dipandang sebagai suatu rantai reaksi yang dimulai dari adanya kebutuhan, kemudian timbul keinginan untuk memuaskannya (mencapai tujuan), sehingga menimbulkan ketegangan psikologis yang akan mengarahkan perilaku kepada tujuan (kepuasan). Barelson dan Steiner mendefinisikan motivasi sebagai suatu keadaan dalam diri seseorang yang mendorong, mengaktifkan atau menggerakkan, dan yang mengarahkan atau menyalurkan perilaku ke arah tujuan (Koontz, 2001:115).

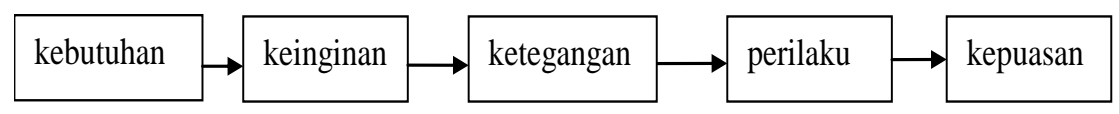

\section{Gambar 1 Rantai Motivasi (Barelson dan Steiner dalam Koontz, 2001:115)}

Teori hierarki kebutuhan yang dikembangkan Maslow (1954) memandang kebutuhan manusia berjenjang dari yang paling rendah hingga paling tinggi, dimana jika suatu tingkat kebutuhan telah terpenuhi, maka kebutuhan tersebut tidak lagi berfungsi sebagai motivator. Hierarki kebutuhan Maslow adalah:

a. Kebutuhan fisik dan biologis, yaitu kebutuhan untuk menunjang kehidupan manusia seperti makanan, minuman, pakaian, dan tempat tinggal. Menurut Maslow, jika kebutuhan fisiologis belum terpenuhi, maka kebutuhan lain tidak akan memotivasi manusia;

b. Kebutuhan akan keselamatan dan keamanan, yaitu kebutuhan untuk terbebas dari bahaya fisik dan rasa takut kehilangan;

c. Kebutuhan sosial, yaitu kebutuhan untuk bergaul dengan orang lain dan untuk diterima sebagai bagian dari yang lain;

d. Kebutuhan akan penghargaan, yaitu kebutuhan untuk dihargai oleh orang lain. Kebutuhan ini akan menghasilkan kepuasan seperti prestige, kekuasaan, status dan kebanggan atas diri sendiri;

e. Kebutuhan akan aktualisasi diri, yaitu kebutuhan untuk mengaktualisasikan semua kemampuan dan potensi yang dimiliki hingga menjadi orang seperti yang dicita-citakan.

Terdapat 2 faktor yang membuat seseorang dapat termotivasi untuk belajar, yaitu: (1) motivasi belajar berasal dari faktor internal. Motivasi ini terbentuk karena kesadaran diri atas pemahaman betapa pentingnya belajar untuk mengembangkan dirinya dan bekal untuk menjalani kehidupan; dan (2) motivasi belajar dari faktor eksternal, yaitu dapat berupa rangsangan dari orang lain, atau lingkungan sekitarnya yang dapat memengaruhi psikologis orang yang bersangkutan. 


\section{Motivasi Belajar}

Berdasarkan berbagai definisi tentang motivasi, disimpulkan motivasi belajar mahasiswa adalah sebagai suatu keadaan dalam diri mahasiswa yang mendorong dan mengarahkan perilakunya pada tujuan yang ingin dicapainya dalam mengikuti pendidikan tinggi. Idealnya, tujuan mahasiswa dalam mengikuti pendidikan tinggi adalah untuk menguasai bidang ilmu yang dipelajarinya. Sehingga dalam mempelajari setiap bahan pembelajaran, mahasiswa terdorong untuk menguasai bahan pembelajaran tersebut dengan baik, dan bukan hanya untuk sekedar lulus meski dengan nilai yang sangat baik sekalipun. Meski secara konseptual tidak ada perbedaan antara menguasai bahan pembelajaran dengan baik dan mendapat nilai baik untuk bahan pembelajaran tersebut, namun dalam dunia pendidikan tinggi swasta di Indonesia dewasa ini, seorang mahasiswa yang lulus dalam suatu bahan pembelajaran dengan nilai baik, belum tentu menguasai bahan pembelajaran tersebut dengan baik.

Sebaliknya, jika seorang mahasiswa mampu menguasai suatu bahan pembelajaran dengan baik, maka hampir dapat dipastikan bahwa dia akan lulus dalam bahan pembelajaran tersebut dengan nilai baik pula. Semuanya ini dapat terjadi, karena metode evaluasi yang ada tampaknya belum bisa menghasilkan ukuran yang obyektif terhadap penguasaan seorang mahasiswa dalam suatu bahan pembelajaran. Untuk mencapai tujuan ideal tersebut, kebutuhan mahasiswa dalam konteks pendidikannya perlu ditingkatkan dari hanya sebagai kebutuhan akan penghargaan (hierarki kebutuhan Maslow), menjadi kebutuhan akan aktualisasi diri. Jika pendidikan tinggi dianggap hanya sebagai kebutuhan akan penghargaan, maka gelar kesarjanaanlah dan bukan penguasaan ilmu yang akan menjadi tujuan utama mahasiswa dalam mengikuti pendidikan tinggi. Sehingga ketika dalam kenyataannya, tujuan itu bisa dicapai tanpa harus susah payah belajar, buat apa pula belajar.

Kelak di akhir proses pendidikannya, mahasiswa sudah merasa puas dapat menyandang gelar kesarjanaan di belakang namanya dan dengan demikian membuatnya bangga. Sebaliknya, jika pendidikan tinggi dianggap sebagai kebutuhan akan aktualisasi diri, maka mahasiswa akan mengeluarkan semua kemampuan dan potensi yang dimilikinya untuk memahami setiap bahan pembelajaran dengan baik. Pada tahap ini, belajar akan menjadi kegemaran yang mengasyikkan karena adanya keinginan atau semangat yang kuat untuk memahami bahan pembelajaran. Kelak di akhir proses pendidikan, dia akan puas dan merasa pantas menyandang gelar kesarjanaannya karena merasa sudah memahami atau menguasai ilmunya.

Seperti pendapat Herzberg (1959) kedua tingkat kebutuhan tersebut, yaitu kebutuhan akan penghargaan dan aktualisasi diri, merupakan faktor motivasi yang bersumber dari dalam diri seseorang (intrinsik). Dengan demikian upaya untuk mengangkat kebutuhan pendidikan tinggi dari hanya sebagai kebutuhan akan penghargaan menjadi kebutuhan akan aktualisasi diri, harus dilakukan dari dalam diri mahasiswa. Instrumen dari perguruan tinggi yang tepat untuk menjalankan tugas ini adalah penasihat akademik yang dijabat oleh seorang dosen.

Penasihat akademik perlu memberi pemahaman kepada mahasiswa bahwa pendidikan tinggi merupakan kesempatan yang baik bagi mahasiswa untuk 
menampilkan semua kemampuan dan potensi yang dimilikinya. Keberadaan penasehat akademik karena ia satu-satunya instrumen dalam perguruan tinggi yang bekerja dari dalam untuk memompa motivasi belajar mahasiswa, sementara instrumen lainnya bekerja dari luar (ekstrinsik). Faktor-faktor intrinsik yang mempengaruhi motivasi belajar mahasiswa ialah: (1) minat terhadap bidang ilmu yang dipelajarinya; dan (2) orientasinya dalam mengikuti pendidikan tinggi. Sementara untuk faktor-faktor ekstrinsiknya ialah: (1) kualitas dosen yang mengajar; (2) bobot materi kuliah yang diajarkan; (3) metode perkuliahan yang digunakan dosen; (4) kondisi dan suasana ruang kuliah; dan (5) fasilitas perpustakaan yang dapat dimanfaatkan oleh mahasiswa. Motivasi mahasiswa diindikasikan dari kepemilikan buku wajib yang dianjurkan dosen, keseriusan dalam mengikuti perkuliahan, frekuensi bertanya pada dosen, kerajinan dalam mengerjakan tugas mandiri, sikap dalam perkuliahan, serta tingkat kehadiran dalam kegiatan perkuliahan.

\section{Faktor-faktor yang Menurunkan Motivasi Belajar}

Motivasi belajar dalam dunia pendidikan merupakan salah satu hal yang penting. Tanpa motivasi, seseorang tentu tidak akan mendapatkan proses belajar yang baik. Motivasi merupakan langkah awal terjadinya pembelajaran yang baik. Pembelajaran dikatakan baik jika tujuan awal, umum dan khusus tercapai. Orang dewasa yang mempunyai need to know / kebutuhan akan keingintahuan yang tinggi, mempunyai karakteristik yang berbeda dalam hal psikologis mereka. Motivasi belajar tentu berkaitan dengan psikologis peserta didik orang dewasa. Terkadang, motivasi belajar dapat pula terpengaruh oleh beberapa sebab, berikut dijabarkan berbagai sebab/faktor yang dapat menurunkan motivasi belajar peserta didik orang dewasa.

a. Kehilangan harga diri

Pengaruh dari hilangnya harga diri bagi orang dewasa sangat besar. Tanpa harga diri, peserta didik orang dewasa akan berlaku sangat emosional dan pasti menurunkan motivasi belajarnya. Penting bagi tutor/guru untuk menyadari hal ini. Berhati-hati dengan latar belakang dan tidak menyinggung perasaan orang lain merupakan hal yang harus diperhatikan tutor/guru untuk peserta didik orang dewasa. Contohnya jika seorang peserta didik orang dewasa dihukum dengan cara maju ke depan dan menjewer kupingnya sendiri dan kakinya diangkat satu, maka niscaya ia tidak akan respek lagi terhadap guru/tutornya dan mungkin materi serta keseluruhan proses belajarnya. Bahkan ia dapat seketika keluar kelas tanpa kembali lagi selamanya.

\section{b. Ketidaknyamanan fisik}

Fisik merupakan aspek fisiologis/penampakan yang penting untuk meningkatkan motivasi belajar. Seorang peserta didik dewasa biasanya selalu memperhatikan penampilan fisiknya. Jika fisiknya tidak membuat ia nyaman, motivasi belajarnya pun akan menurun. Contoh; seorang yang mempunyai badan yang besar akan mengalami penurunan motivasi jika ia diminta untuk belajar lari sprint dilapangan. 


\section{c. Frustrasi}

Kendala dan masalah hidup yang dihadapi oleh orang dewasa merupakan hal yang harus dijalani. Terkadang dapat diatasi, terkadang tidak. Mereka yang mengalami masalah yang tidak tertanggulangi biasanya akan cepat frustrasi. Peserta didik seperti ini tentu fokus utamanya menghadapi problem hidupnya yang sedang carut-marut itu. Motivasi untuk terus belajar akan menurun sejalan dengan rasa frustrasinya. Tutor/guru seharusnya dapat memahami apa yang dihadapi peserta didiknya. Tutor/guru harus dapat menyampingkan rasa frustrasi peserta didiknya dengan menjadikan proses pembelajaran sebagai sesuatu yang menyenangkan dan refreshing.

d. Teguran yang tidak dimengerti

Orang dewasa tidak hanya manusia yang mempunyai pemikiran dan pengalaman luas ttapi juga prasangka yang besar pula. Jika tutor/guru menegur dengan tanpa ia mengerti, peserta didik orang dewasa itu pun akan merasa bingung dan berprasangka macam-macam yang pada akhirnya menjadi faktor penurun motivasi belajarnya. Contohnya, tutor/guru yang kesal dengan peserta didiknya yang terlambat menacung-acungkan jari dengan cepat kepada peserta didik tersebut. Peserta didik orang dewasa tersebut tentu bingung dan berfikir apa yang salah dengannya, dan ia berinisiatif untuk tidak menghadiri kelas tersebut, mungkin untuk selamanya.

e. Menguji yang belum dibicarakan/diajarkan

Tutor/guru yang tidak memahami peserta didiknya dan mempunyai jam terbang rendah, nampaknya kesulitan dan dapat saja ia lupa atau sengaja untuk menampilkan soal-soal ujian yang sulit atau belum diajarkanya karena berbagai sebab. Peserta didik orang dewasa yang mengikuti pembelajarannya akan tidak dapat menjawab atau menjawab dengan kurang tepat sehingga mereka merasa kesal atau merasa dipermainkan tutornya. Hal ini menjadi kontraproduktif terhadap proses pembelajaran tersebut.

f. Materi terlalu sulit/mudah

Materi pembelajaran dapat diukur dengan menerapkan pratest dan pengidentifikasian sasaran peserta didik. Terkadang hal ini tidak diperhatikan tutor/guru sehingga materi yang diajarkan terlalu sulit/mudah. Bagi peserta didik orang dewasa, mereka tentu sangat bosan dengan materi yang terlampau mudah dan sangat frustasi dengan materi yang terlampau sulit. Keduanya mempengaruhi motivasi belajar peserta didik ketingkat terendah. Ada beberapa strategi yang bisa digunakan untuk menumbuhkan motivasi belajar siswa, ialah: (1) menjelaskan tujuan pembelajaran pada peserta didik; (2) hadiah; (3) saingan/kompetisi; (4) pujian; (5) hukuman; (6) mengembangkan dorongan kepada mahasiswa untuk belajar; (7) membentuk kebiasaan belajar yang baik; (8) membantu kesulitan belajar siswa secara individual maupun kelompok; (9) menggunakan metode yang bervariasi; dan (10) menggunakan media yang baik dan sesuai dengan tujuan pembelajaran. 


\section{METODE PENELITIAN}

Penelitian ini menggunakan rancangan penelitian deskriptif. Menurut Sukmadinata (2005) penelitian deskriptif adalah sebuah bentuk penelitian yang paling dasar yang ditunjukkan untuk mendeskripsikan atau menggambarkan fenomena-fenomena yang ada baik fenomena yang bersifat ilmiah ataupun rekayasa manusia. Hal senada dikemukakan oleh Suryabrata (2003) yang mengemukakan bahwa tujuan penelitian deskriptif adalah untuk membuat pencandraan secara sistematis, faktual dan akurat mengenai fakta-fakta, dan sifat populasi dan daerah tertentu. Penelitian ini dilakukan di Fakultas Ekonomi Universitas Negeri Malang selama empat bulan terhitung dari bulan April 2005 sampai dengan bulan Agustus 2005. Penelitian ini menghubungkan satu variabel bebas dan variabel terikat. Variabel bebas, yaitu faktor-faktor yang diduga memiliki pengaruh terhadap motivasi belajar mahasiswa Fakultas Ekonomi Universitas Negeri Malang, yang diukur dari: faktor-faktor intrinsik dan ekstrinsik. Variabel terikat, yaitu motivasi belajar mahasiswa Fakultas Ekonomi Universitas Negeri Malang, yang diukur dari informasi mengenai: frekuensi kepemilikan buku wajib oleh dosen, frekuensi bertanya pada dosen, kerajinan dalam mengerjakan tugas mandiri, sikap dan tingkat kehadiran dalam kegiatan perkuliahan.

Populasi dari penelitian ini adalah mahasiswa dari jurusan Manajemen dan Akuntansi yang masih aktif mengikuti kegiatan perkuliahan. Sedangkan sampelnya dipilih dengan pertama-tama mengelompokkan mereka dalam jurusan Manajemen dan Akuntansi kemudian dari tiap jurusan tersebut dipilih sampel secara berjenjang dari angkatan tahun 2002, 2003, dan 2004. Penetapan batas awal tahun angkatan 2002 dengan pertimbangan bahwa mahasiswa angkatan tahun ini masih aktif, sedangkan penetapan batas akhir tahun 2004 dengan pertimbangan bahwa mahasiswa tahun angkatan itu telah memiliki pengalaman yang cukup. Dengan kata lain, batas minimal pengalaman yang dianggap cukup adalah jika mahasiswa tersebut telah mengikuti pendidikan selama satu tahun dan batas maksimal empat tahun.

\section{HASIL PENELITIAN DAN PEMBAHASAN}

\section{Hasil Penelitian} Tabel 1.

Berdasarkan deskripsi sampel diketahui profil responden seperti pada

Tabel 1.1 Profil Responden Berdasarkan Jurusan dan Angkatan

\begin{tabular}{lccc}
\hline \multirow{2}{*}{ Angkatan } & \multicolumn{2}{c}{ Jurusan } & \multirow{2}{*}{ Total } \\
\cline { 2 - 3 } & Manajemen & Akuntansi & \\
\hline Angkatan 2002 count & 20 & 20 & 40 \\
$\%$ within jurusan & $32,3 \%$ & $29,9 \%$ & $31,0 \%$ \\
Angkatan 2003 count & 20 & 22 & 42 \\
$\%$ within jurusan & $32,3 \%$ & $32,8 \%$ & $32,6 \%$ \\
Angkatan 2004 count & 22 & 25 & 47 \\
$\%$ within jurusan & $35,5 \%$ & $37,3 \%$ & $36,4 \%$ \\
Total count & 62 & 67 & 129 \\
$\%$ within jurusan & $100 \%$ & $100 \%$ & $100 \%$ \\
\hline
\end{tabular}


Penelitian ini menganalisis data dan informasi yang dikumpulkan dari sampel sebanyak 129 mahasiswa, yang terdiri atas 67 mahasiswa Akuntansi dan 62 mahasiswa Manajemen yang berasal dari angkatan tahun 2002, 2003, dan 2004.

Tabel 2 Karakteristik Motivasi Belajar Mahasiswa Fakultas Ekonomi UM

\begin{tabular}{cccccccc}
\hline \multirow{2}{*}{ No } & \multirow{2}{*}{ Indikator } & \multicolumn{6}{c}{ Mayoritas mahasiswa } \\
\cline { 2 - 7 } & \multicolumn{2}{c}{ Jurusan Manajemen } & \multicolumn{2}{c}{ Jurusan Akuntansi } & \multicolumn{2}{c}{ Fakultas Ekonomi } \\
\cline { 2 - 7 } & Frekuensi & \% & Frekuensi & \% & Frekuensi & $\%$ \\
\hline 1 & $\begin{array}{l}\text { Memiliki } \\
\text { buku wajib }\end{array}$ & Sering & 40,3 & Kadang & 49,3 & Kadang & 38,8 \\
2 & $\begin{array}{l}\text { Menyimak } \\
\text { perkuliahan }\end{array}$ & Sering & 58,1 & Sering & 56,7 & Sering & 57,4 \\
3 & $\begin{array}{l}\text { Bertanya pada } \\
\text { dosen }\end{array}$ & Kadang & 37,1 & Kadang & 47,8 & Kadang & 42,6 \\
4 & $\begin{array}{l}\text { Mengerjakan } \\
\text { tugas mandiri }\end{array}$ & Sering & 59,7 & Sering & 58,2 & Sering & 58,9 \\
5 & $\begin{array}{l}\text { Ngobrol saat } \\
\text { kuliah }\end{array}$ & Jarang & 46,8 & Kadang & 49,3 & Kadang & 42,6 \\
6 & Bolos kuliah & Jarang & 69,4 & Jarang & 62,7 & Jarang & 65,9 \\
\hline
\end{tabular}

Jika motivasi belajar mahasiswa Fakultas Ekonomi Universitas Negeri Malang dibandingkan antara jurusan Akuntansi dan Manajemen, maka dapat dikatakan bahwa motivasi belajar mahasiswa jurusan Manajemen relatif lebih baik dibanding motivasi belajar mahasiswa jurusan Akuntansi. Diantaranya, mahasiswa jurusan Manajemen lebih sering memiliki buku wajib yang dianjurkan dosen dan lebih jarang ngobrol saat perkuliahan sedang berlangsung. Sementara, meski mahasiswa di kedua jurusan sama-sama sering menyimak perkuliahan dan mengerjakan tugas mandiri serta jarang bolos kuliah, namun proporsi mahasiswa yang melakukannya relatif lebih banyak di jurusan Manajemen dibanding Akuntansi.

\section{Pembahasan}

Motivasi belajar tidak akan terbentuk apabila orang tersebut tidak mempunyai keinginan, cita-cita, atau menyadari manfaat belajar bagi dirinya. Oleh karena itu, dibutuhkan pengkondisian tertentu, agar diri kita atau siapa pun juga yang menginginkan semangat untuk belajar dapat termotivasi. Tips-tips berikut adalah untuk meningkatkan motivasi belajar peserta didik, yaitu:

a. Bergaul dengan orang-orang yang senang belajar

Bergaul dengan orang-orang yang senang belajar dan berprestasi, akan membuat kita pun gemar belajar. Selain itu, coba cari orang atau komunitas yang mempunyai kebiasaan baik dalam belajar. Bertanya tentang pengalaman di berbagai tempat kepada orang-orang yang pernah atau sedang melanjutkan pendidikannya ke jenjang yang lebih tinggi, orang-orang yang mendapat beasiwa belajar di luar negeri, atau orang-orang yang mendapat penghargaan atas sebuah prestasi. Kebiasaan dan semangat mereka akan menular kepada kita. Seperti halnya analogi orang yang berteman dengan tukang pandai besi atau penjual minyak wangi. Jika kita bergaul dengan tukang pandai besi, maka kita pun turut 
terciprat bau bakaran besi, dan jika bergaul dengan penjual minyak wangi, kita pun akan terciprat harumnya minyak wangi.

b. Belajar apapun

Pengertian belajar di sini dipahami secara luas, baik formal maupun nonformal. Kita bisa belajar tentang berbagai keterampilan seperti merakit komputer, belajar menulis, membuat film, dan berlajar berwirausaha.

c. Belajar dari internet

Kita bisa memanfaatkan internet untuk bergabung dengan kumpulan orang-orang yang senang belajar. Salah satu milis dapat menjadi ajang kita bertukar pendapat, pikiran, dan memotivasi diri. Sebagai contoh, jika ingin termotivasi untuk belajar bahasa Inggris, kita bisa masuk ke milis.

d. Bergaul dengan orang-orang yang optimis dan selalu berpikiran positif

Di dunia ini, ada orang yang selalu terlihat optimis meski masalah merudung. Kita akan tertular semangat, gairah, dan rasa optimis jika sering bersosialisasi dengan orang-orang atau berada dalam komunitas seperti itu, dan sebaliknya.

\section{e. Cari motivator}

Kadangkala seseorang butuh orang lain sebagai pemacu atau mentor dalam menjalani hidup. Misalnya: teman, pacar, ataupun pasangan hidup. Kita pun bisa melakukan hal serupa dengan mencari seseorang/komunitas yang dapat membantu mengarahkan atau memotivasi kita belajar dan meraih prestasi.

\section{E. SIMPULAN}

Dewasa ini, seiring dengan pertumbuhan perguruan tinggi yang makin pesat, maka tingkat persaingan di antara perguruan tinggi dalam memperebutkan calon mahasiswa, juga menjadi semakin ketat. Hanya tersedia satu jalan bagi perguruan tinggi yang ingin bertahan dalam persaingan tersebut, yaitu melalui kualitas lulusan yang dihasilkannya. Terdapat dua faktor yang membuat seseorang dapat termotivasi untuk belajar, yaitu: (1) motivasi belajar berasal dari faktor internal. Motivasi ini terbentuk karena kesadaran diri atas pemahaman betapa pentingnya belajar untuk mengembangkan dirinya dan bekal untuk menjalani kehidupan; dan (2) motivasi belajar dari faktor eksternal, yaitu dapat berupa rangsangan dari orang lain, atau lingkungan sekitarnya yang dapat memengaruhi psikologis orang yang bersangkutan.

Faktor-faktor intrinsik yang mempengaruhi motivasi belajar mahasiswa ialah: (1) minat terhadap bidang ilmu yang dipelajarinya; dan (2) orientasinya dalam mengikuti pendidikan tinggi. Sementara untuk faktor-faktor ekstrinsiknya ialah: (1) kualitas dosen yang mengajar; (2) bobot materi kuliah yang diajarkan; (3) metode perkuliahan yang digunakan dosen; (4) kondisi dan suasana ruang kuliah; dan (5) fasilitas perpustakaan yang dapat dimanfaatkan oleh mahasiswa. 


\section{DAFTAR RUJUKAN}

Berliner, G. 1993. Educational Psychology, Third edition. Boston: Houghton Miffin Company.

Borg, W., dan Gall, M.D. 1979. Educational Research: An Introduction, Third Edition. New York: Longman Group Limited.

Fosnot, C. T. 1996. Constructivism: Theory, Perspectives, and Practice. London: Teachers College Press, Columbia University.

Gibson, J. L. 2002. Organisasi dan Manajemen: Perilaku, Struktur, Proses. Jakarta: Penerbit Erlangga.

Hageman, G. 2000. Motivasi Untuk Pembinaan Organisasi. Jakarta: Pustaka Binaman Pressindo.

Hergenhahn, B.R., dan Olson, M.H. 2008. Theories of Learning. London: Pearson Education.

Koontz, H. 2001. Manajemen. Jakarta: Penerbit Erlangga.

Sardan. 2002. Tantangan Perguruan Tinggi Swasta dalam Menghadapi Era Globalisasi dan Industrialisasi. Jakarta: Penerbit Erlangga.

Sukmadinata, N. S. 2005. Metode Penelitian Pendidikan. Bandung: PT Remaja Rosdakarya.

Suryabrata, S. 2003. Metodologi Penelitian. Jakarta: Raja Grafindo Persada.

Woolfolk, A.E. 1995. Educational Psychology. London: Allyn and Bacon. 